\title{
THE ISLAMIC RELIGIOUS EDUCATION TEACHERS'S ROLE IN MOTIVATION THE STUDENTS TO LEARN IN GRADE 7 SCHOOL MUHAMMADIYAH 3 PADANG
}

\author{
Ahmad Lahmi ${ }^{1}$ and Husni Padri ${ }^{2}$ \\ Universitas Muhammadiyah Sumatera Barat \\ e-mail:damhaimhal@yahoo.co.id
}

\begin{abstract}
Abstrack
As for the focus of this research are as follows: (1) What are the efforts of Islamic religion teachers in motivation the students to learn in grade 7 School Muhammadiyah 3 Padang, (2) What are the obstacles encountered the Islamic religious education teachers in motivation the learners in grade 7 School Muhammadiyah 3 Padang. The purpose of this research is to explain as follows: (1) To know the Islamic religious education teacher's efforts in motivation the learners to learn in grade 7 School Muhammadiyah 3 Padang, (2) To know the obstacles encountered the Islamic religious education teachers in motivation the learners to learn in grade 7 School Muhammadiyah 3 Padang. This kind of research is naturalistic qualitative descriptive that describes the studied what is and is not engineered. The informant of this research is The Islamic religious education teachers and learners in grade 7 School Muhammadiyah 3 Padang. To get the dates of this research is to use data collection techniques such as interviews, observation, and documentation. As for the yields of this research is obtained that the efforts of Islamic religious education teachers in motivation the learners to learn in grade 7 School Muhammadiyah 3 Padang are as follows; providing motivation to students or encouragement prior to start the learning, explaining the benefits and goals of the learning, choose the way presentation varies, provide convenience and assistance in learning, give praise, rewards or gifts, reward for personal protégé. Based on the results obtained it can be concluded that the efforts of the teachers of

\footnotetext{
Lecturer at Faculty of Islamic Religion of Muhammadiyah University of West Sumatera Sumatera
}

2 Student at Islamic Religious Education of Islamic Religion of Muhammadiyah University of West
\end{abstract}


Islamic education in motivating students to learn in class VIII SMP Muhammadiyah 3 Padang is: give motivation or encouragement before the learning begins, explain the benefits and purpose of learning is given, choose the way presenting a varied, provide convenience and assistance in learning, give praise, rewards or prizes, and rewards the child's personal. The constraints faced by teachers of Islamic education in motivating students to learn in class VIII SMP Muhammadiyah 3 Padang is: Facilities and infrastructure are inadequate, the time allocation insufficient, reference books are incomplete, the interest of learners who are less, the environment less family support and lack of budget for gifts. The suggestions in the discussion of this paper are: (1) the researchers suggest to the school in order to give high attention to learners so that learners are more motivated to learn and also to provide complete facilities such as reference books related to Islamic education, and instructional media for the achievement of learning objectives. (2) to the teachers, especially teachers of Islamic education in order to further optimize the role in motivating students to learn, such as using media in teaching and learning so that the learning activities more interesting and stimulating learners to be more active learning.

Keywords: Teacher of Islamic religious education, motivation

\section{A. Background of the Problem}

Islamic education is very urgent in human forming strong personality and good, as well as a spearhead in the moral development of the nation. Given the importance of Islamic education in the life of this nation, the Islamic Religious education keeping a very strategic position. Urgency, purpose and position of education can be seen in article 3 of Law No. 20 of 2003 on national education: "National education serves to develop the ability and character development and a dignified civilization in order to achieve the life of God Almighty, the noble character, healthy, knowledgeable, capable, creative, independent, and become citizens of a democratic and responsible"3

To achieve the goals of Islamic Education as above, this would need to be supported by all educational actors. Teachers as actors of education, which is one component of the learning process has a very important role in determining the quality of learning undertaken, in order to reach the expected

Redaksi Citra Umbara (2006), Undang-Undang Republik Indonesia Nomor 20 Tahun 2003 Tentang Sistem Pendidikan Nasional, Bandung: Citra Umbara, p. 76. 
goals. Therefore, teachers should play an active role to put his position as professionals in accordance with the guidance of community that continues to grow.

\section{B. Study of Literature}

The teacher as an educator, in Islam is seen as a very noble task. This position causes why Islam puts those who believe and learned knowledge is higher in rank when compared with humans sharing. It is as contained in the word of Allah in the Surah al-Mujadalah, verse 11, as follows:

Meaning: Oye who believe! When it is said unto you: 'Give spaciousness in the majlis-majlis, "So lapangkanlah Allah will give you spaciousness. And when it is said: "Stand up, then stand Allah will lift (degrees) those who believe among you and those who have knowledge of knowledge some degree. And Allah is careful about what you do. ${ }^{4}$

The teacher's task in directing and guiding learners that increased knowledge, behaviour change toward the good, the more proficient skills, increasingly built up, and developing potential. Good teachers and professionals are teachers who can motivate (push) the learners to learn, so as to achieve the learning objectives. In this case Zakiah Daradjat say that "religion teachers not only provide mere knowledge, but should provide a good impetus and guidance in accordance with the purpose of education and teaching"5

In operation, Hasan Langgulung argued that: educating a series of teaching process, providing encouragement, praise, punishment, to give an example, familiarize, and so forth. This limitation meant that the task of educators is not just teaching as the opinion of most people. In addition, educators also served as a motivator and facilitator in the learning process, so that all potential learners can be actualized in good and dynamic. ${ }^{6}$

4 Depertemen Agama RI Al-Hikmah (2007), al-Qur'an dan Terjemahnya, Bandung: Diponegoro, tenth edition, p. 543

Zakiah Daradjat (1993), Ilmu Pendidikan Islam, Jakarta: PT. Bumi Aksara, tenth edition, p. 543

Hasan Langulung (1996), Pendidikan Agama Islam Menghadapi Abad ke - 21 Jakarta: pustaka Pustaka Al-husna, p. 123. 
Of the various roles above shows that the teacher serves as a motivator, that encourage learners to foster activity and creativity. Therefore, the Islamic religion teachers are required to take advantage of its role in motivating students to learn that the learning process goes well that can give birth to learners active and creative. Given this role is expected activities of the learning process is not running with emptiness, but full of meaning which provide stimulus for learners to be more active and creative. Teachers do not only concern itself with the content presentation maximizing activity alone, which is more important that teachers think about how students learn, as indeed educate participants as a major subject in the study.

Learning is a process that is inherent in self-learners, and also very meaningful in life. To further increase the significance of learning, the process must be guided by a profound awareness that includes awareness of emotional, intellectual, spiritual, social and cultural. By because the learning process is placed in a situation that is conducive to actually achieve the goals and objectives. ${ }^{7}$

To create effective teaching and learning conditions and conducive, teachers are highly demanded an active role in the learning of students. Teachers teach and learners to learn, a fusion of two human element is born of educational interaction that utilizes teaching materials as a medium. There all the learning component that has been set before the study carried out. ${ }^{8}$

Learning activities intended to create conditions that allow the process of learning on the learner. According to Slameto that the study is "a process attempts person to obtain a new behavior changes as a whole, a result his own experience in interacting with the environment."

From the above understanding, it can be an understanding that in a learning activity can be said to occur study, if there is a change of behavior on the self-learners as a result of an experience. Teachers can help students learn, but teachers can't learn for the learner, meaning that learning occurs

7 Nursid Sumatmadja (2002), Pendidikan Pemanusiaan Manusia Manusiawi, Bandung: Alfa Beta, p .27 .

8 Syaiful Bahri Djamarah dan Aswan Zeim (2003), Strategi Belajar Mengajar, Jakarta: Rineka Cipta, fourth edition, p.2.

9 Slameto (2002 ), Belajar dan Faktor yang mempengaruhinya, Jakarta: Rineka Cipta, p. 43. 
within the individual, can' t be transferred to other people. Here it can clearly be seen that the ultimate goal must be to make the organization of learning activities of learners to learn so that learners how to be considered as a subject in education that will eventually give birth to learners active and creative..

In an effort to make learners to learn, teachers are required to have multiple roles so as to create an effective teaching and learning conditions. ${ }^{10}$ One of the players is as a motivator, motivation is important for students because of the motivation for someone to be compelled to perform an activity or activities. In this case, according to Oemar Hamalik, that the function of motivation is:

1. Motivation serves as a director, it means directing actions to achieve the desired goal.

2. Motivation serves as a driver, it means moving tigkahlaku someone. The size of motivation will determine sooner or later a job. ${ }^{11}$

From the above understanding can be understood that the role of motivation is essential to achieve the desired goal. In the role of motivation in learning activities are required both intrinsic and extrinsic. Motivation for learners to develop activities and initiatives. In Islamic education, motivation to learn is important for students as a factor for driving an active role in the learning process in order to acquire knowledge and skills. Motivation to learn is important for students because it will get better learning results.

In the study there are intrinsic and extrinsic motivation. This motivation needs to be optimized so that learners more passionate and active in their learning. in the sense that so, then between learning motivation and learning outcomes of students there is a correlation and causality. If the note verses of the Koran and Hadith there are lots of which implies learning motivation and varied forms. There is a form of promises, threats, the parables of which are contained in the words of Allah surah AZ-Zumar verse 9 as follows:

Meaning: Meaning: $O$ ye idolaters, whether you are more fortunate or those who dutifully and faithfully worship night prostrating and standing

10 Moh .Uzer Usman (2003), Menjadi Guru Propesional, Bandung: PT Remaja Rosdakarya. p. 15.

11 Oemar Hamalik (2003), Kurikulum dan Pembelajaran, Jakarta: Bumi Aksara. h. 108. 
fear the torment of the Hereafter and expect the grace of god? say: "is there the same people who know people who do not know?" only people who have a mind that can receive lessons " 12

To raise the motivation that exist within a person it is in need motivation from outside oneself that if only rely on the motivation of the individual self motivation then over time it will weaken itself either because of saturation as well as environmental influences are less supportive.

From observations and interviews while researchers for implementing Program Field Experience in SMP Muhammadiyah 3 fields, the motivation of learners into problems, low motivation of learners in following subjects Islamic Education, for example in teaching and learning take place, learners less attention to teacher is explaining a lesson, and this is also seen in students who frequently ask permission out, and spoke with his friend when the teacher explains the lesson, often late or leaving school hours education class on Islam.

In the researchers conducted observations and interviews while, the researchers had asked one of the students named Arif Kurniawan who often go out without permission and he replied lazily follow the lesson, and also ask why talk when the teacher explains and she gave reasons for sleepy and less vibrant.

From the above phenomena, the researcher is interested in studying more in depth about "How Role of Islamic Education Teachers in Motivating Students Learning in Class VIII SMP Muhammadiyah 3 Padang”.

Various ways can be done so that learners are motivated to learn. Teachers who successfully teaching is the teacher who knows how to generate interest students in learning, with memamfaatkan extrinsic motivation in various forms, namely:

1) Giving numeral.

Figures in this case as a symbol of the value of learning activities. Many students learn, the main precisely to achieve a good number or value. So that learners usually pursued is the replay value or values to report good numbers. The numeral both for learners is a very strong motivation

12 Depertemen Agama RI, (2007), al-Qur'an dan Terjemahnya, p. 45. 
2) Prize

Gifts can also be regarded as motivation, because students can be motivated participants with prizes that will be given by the teacher, but it is not always the case. Because the reward for a job, it may not be attractive to someone who is not happy and talented for such a job.

3) The Rivals / competence.

Rivals or competition can be used as a motivational tool to encourage learners to learn. Competition, rivalry both individual and group competition can improve the performance of learners.

4) Ego-involvemen

Raise awareness to the students to feel the importance of the task and accept it as a challenge to work hard at the risk of self-esteem, is as a form of motivation is quite important. Someone will strive with all our strength to achieve good performance with keeping his self-esteem. The completion of a job well done is a symbol of pride and self-esteem, as well as for learners of the subject of study. Learners will study hard could be because of pride.

5) Giving repetition.

The students will study harder knowing if there is a repeat. Therefore, give this test is also a means of motivation. But it should be remembered by teachers, is not too often (example, every day) because it can be boring and routine. In this case the teacher must also be open, meaning if will replay must be notified to the learners.

6) Knowing the results.

By knowing the results of the work, especially if progress is made, will encourage learners to study harder. Getting to know that the graph of the results of learning increases, then there is no motivation to self-learners to continue learning, with a hope that the results continue to rise.

7) Praise.

If there is a successful learners who successfully complete the task properly, should be given praise. This praise is a form of positive reinforcement and is a good motivation. Therefore, in order to compliment this is the 
motivation, the gift must be precise. With proper praise will foster a pleasant atmosphere and heightens the passion to learn and at the same time will raise self-esteem.

8) Penalties.

Punishment as negative reinforcement, but when given correctly and wisely can be a motivational tool. By because teachers must understand the principles of sentencing.

9) The desire to learn.

The desire to learn, meaning no intention, no intention to learn. It would be better, when compared to all the activities without intent. The desire to learn means that the students themselves was indeed no motivation to learn, of course, of course, the result will be better.

10) Interest.

Motivation is closely related to interest, motivation appeared because of the need, as well as interest so it was fitting that the interest is a fundamental motivational tool. The learning process will run smoothly if accompanied by an interest. Regarding this interest can be generated by means of the following:

a) Raise the existence of a necessity.

b) Connecting with the issue of past experience.

c) Provide an opportunity to get good results.

d) Using various forms of teaching.

11) An objective recognized

The formulation of objectives is recognized and accepted by learners, will constitute a very important motivational tool. Because by understanding the objectives to be achieved, because it is considered very useful and beneficial, then there will be a passion to keep learning. ${ }^{13}$

With the ways that can cause extrinsic motivation over the teachers are expected to capitalize upon a number of ways according to the circumstances of learners. In the process of learning the role of intrinsic and extrinsic

$13 \quad$ Ibid, p. 92. 
motivation is necessary, because they both serve as a spur people to behave perfectly based on religious values of Islam, as a determinant of the direction of human action itself as Allah described in Holy Quran Surah Al-Baqarah verse $81-82$ as follows:

Meaning: "not so whoever sinned and he has been overwhelmed by sin, they are the dwellers of the Fire, to dwell therein. And those who believe and do good works they were inhabitants of heaven; they will abide therein"'l4

From the above paragraph according to al Maraghi's interpretation that "persons covered by stain and sin that makes him a slave of lust, then he is entitled to remuneration hell, contrary to those who carry out the obligations of the well and stopped from committing immoral acts, they are those who got in return is keeping heaven as the penalty on those who are sincere charity towards Allah. Both physically and mentally ${ }^{15}$

This study is qualitative. Considerations in determining the type of qualitative research is that this research problem concerns policies and the desired data is in the context of what is without controlling certain variables. Qualitative research departs from special cases are based on real experience (speech or behavioral research subjects or the situation in the field of experience), then formulated into a model, concept, principle theories, and the definition of a general nature. ${ }^{16}$

\section{Procedures and Stages of Qualitative Research:}

1. Set the focus of research

Qualitative research procedures based on inductive logic thinking that is highly flexible planning research. Qualitative studies must go through the stages and procedures of research that has been set. The first thing that must be done before through all phases of the study

14 Departemen Agama Republik Indonesia, (2007), al-Qur'an dan Terjemahnya, p. 12.

15 Ahmad al-Mustafa al-Maraghi (1992), Terjemahan Tafsir al-Maraghi, Semarang: CV. Toha Putra, p. 276-277.

16 Dedy Mulyana (2008), Metodelogi Penelitian Kualitatif, Bandung: PT. Remaja Roskaya, p. 156 
is to establish the research question is referred to as "the focus of research", is a question of the things we wanted to answer through the research.

2. Determine the setting and subject of study

Setting research shows that the community will be examined and at the same physical and social conditions. Setting the research will reflect the location of the research. These research subjects into the research informants such as: first, key informants are aware and have the basic information required in the study, the second major source of information that involve direct social interaction researched, third, that additional informants provide information directly and indirectly.

3. Data collection, data processing, and data analysis

In data collection methods used in qualitative research is to conduct surveillance or observation and in-depth interviews or in-depth interview. Qualitative data processing in research done by classified or to categorize the data based on the theme according to a research focus. The data analysis can be done in grounded research.

4. Presentation of data

The basic principles of data presentation is to give an understanding of something in others. Data obtained in the form of words and not in the form of numbers, the presentation is usually a description of the words and not in the form of tables in the statistical measures. Data presented often in the form of direct quotations from interviewees own words. ${ }^{17}$

In this study, researchers will also follow the steps as mentioned above. Its application will be adjusted to focus the study as stated in the research purposes.

17 Suyanto, Bagong \& Sutinah, (2005), Metode Penelitian Sosial Berbagai Alternatif Pendekatan, Surabaya: Kencana Prenada Media Group, p. 170-173. 


\section{Results of the Research}

1. Efforts made Islamic Education teachers in motivating students to learn in class VIII SMP Muhammadiyah 3 Padang Ujung Belakang Olo is: Teachers provide encouragement before the learning begins, explain the benefits and purpose of learning is given, choose a way of presenting a varied, provide convenience and assistance in learning, give praise, rewards or prizes, and rewards the child's personal

2. Constraints faced by teachers of Islamic education in motivating students to learn in class VIII SMP Muhammadiyah 3 Padang Ujung Belakang Olo. Facilities and infrastructure are inadequate, the allocation of time is less, the book reverensi less, the interest of learners who are less, less supportive family environment and lack of budget for gifts.

\section{E. Suggests and Implication of Research}

From the results of this research is researcher suggesting to various parties associated with education in order to improve the motivation of learners studying Islamic Education..

1. To the school in order to give high attention to learners so that learners are more motivated to learn and also to provide complete facilities such as: reverence books related to Islamic education, and instructional media for the achievement of learning objectives.

2. To the teachers, especially teachers of Islamic education in order to further optimize the role in motivating students to learn, such as using media in teaching and learning so that the learning activities more interesting and stimulating learners to be more active learning. 


\section{BIBLIOGRAPHY}

Daradjat, Zakiah, dkk, Ilmu Pendidikan Islam, Jakarta: PT.Bumi Aksara 1993

Depertemen Agama Republik Indonesia, Al- Hikmah, Al Quran danTerjemahnya, Bandung Diponegoro, 2007.

Ekosusilo, Madyo, Dasar-Dasar Pendidikan, Semarang: Effar Offset, 1998.

Hamalik, Oemar, Kurikulum dan Pembelajaran. Jakarta: PT. Bumi Aksara, 2013.

Kasijen, Psikologi Pendidikan, Surabaya: Bina Ilmu, 1984.

Langgulung, Hasan, Pendidikan Islam Menghadapi abad ke-21, Jakarta: Pustaka Al-Husna, 1996.

Malik, Abdul dan Dian Andayani, Pendidikan Agama Islam Berbasis Kompetensi, Konsep dan Implementasi Kurikulum 2004, Bandung: Rosda Karya, 2004.

M. Dalyono, Psikologi Pendidikan, Jakarta: PT. Rineka cipta, 2010

Moelong, J. Lexy, Metodologi Penelitian Kualitatif, Jakarta: Remaja Rosdakarya, 2013. 